\title{
Assessing Crisis Management Competencies: A Case Study of Pasir Gudang City Council
}

\author{
Norlina Muhammad \\ Faculty of Educational Studies, \\ Universiti Putra Malaysia,43400, Selangor, Malaysia \\ Ismi Arif Ismail (Corresponding Author) \\ Faculty of Educational Studies, \\ Universiti Putra Malaysia,43400, Selangor, Malaysia \\ Mohd Mursyid Arshad \\ Faculty of Educational Studies, \\ Universiti Putra Malaysia,43400, Selangor, Malaysia \\ Ahmad Aizuddin Md Rami \\ Faculty of Educational Studies, \\ Universiti Putra Malaysia,43400, Selangor, Malaysia
}

Received: Oct. 3, $2021 \quad$ Accepted: Nov. 15, $2021 \quad$ Online published: Nov. 22, 2021

doi:10.5296/ijhrs.v11i4S.19238 URL: https://doi.org/10.5296/ijhrs.v11i4S.19238

\begin{abstract}
In this modern era of globalisation, the role of leaders and employees in handling crises and problems is very important. This study aims to gather as much understanding as possible through different perspectives. This study was conducted using qualitative methods involving eight informants in a number of in-depth interviews until data saturation has been reached. During the interview sessions, questions were asked based on the preparation of an interview protocol. Data analysis discovered four main themes related to crisis management competencies, namely "excellent work culture", "dynamic thinking competency learning",
\end{abstract}


"efficient organisational production", and "responsive governance development".Overall, the data acquisition indicates that crisis management competencies give further understanding to employees on how to deal and handle upcoming crisis and to prepare it from happening in the future. At the same time, the management and employees need to implement organisational learning as a process to formulate strategies and improve the service quality to external parties such as customers and stakeholders.

Keywords: leaders, organisational development, organisational learning, work culture

\section{Introduction}

Human resource development is an essential mechanism for developing a successful organisation. In line with the technological needs and strong global competition specifically in the administrative landscape, human resource competencies need to be enhanced from time to time. According to Fauziah (2019), the organisation faces tough competition and obstacles along with its human resource growth. Organisations need to initiate an orderly work process at all times with the existing number of employees based on their competencies. This will give a positive return when the human resource management has successfully implemented the given tasks in accordance with the standards and requirements. A successful organisation is determined by the quality and capabilities of employees (Ghozali et al., 2020). In addition, human resources are perceived to provide the best service when the organisation recognises the competency growth of each employee.

One of the recent challenges faced in this modern period is the importance of human resource development with its strategic approaches to ensure employees' success in achieving objectives and enhancing the efficiency of the organisation. Other than that, the organisation needs employees with a high level of competence (Zaleha et al., 2017). For instance, highly competent or knowledgeable employees are essential in the aspects of communication, information technology, and governance. On the other hand, several weaknesses of the organisation are lack of human resources related to the organisational needs, due to having many unskilled, uncompetitive, low high performance, and low productivity employees (Yostan, 2019). According to Watts in the Journal of Human Capital Development, as written by Norhani and Yoong (2009), the technological advancements and era of globalisation require current organisations to quickly act and implement changes. Other issues are to implement a high quality service delivery in the organisation (Beram et al., 2020). Thus, it is important to identify high competency workers according to their abilities and capabilities in order to ensure organisational success (Zaenudin, 2018; Triyanto \& Sudarwati, 2014).

The competency aspect in any organisation is critical as it is one of the main cores in human resource development. Beram et al. (2020) highlighted the competency practices among civil servants as stated by the Public Service Department. The improvement of human resources is measured with the employees' ability, which is the basic individual characteristics required in performing any tasks (Lenggan, 2019). According to Rusle (2018), Hecklau et al. (2016) introduced several relevant competencies of an individual for the benefits of the organisation, namely technical, methodological, personal, and social competencies. 
In developed countries, many organisations demonstrate their success through effective or practical human resource development as well as the enhancement of their employees' skills and expertise. Besides, in this fast-paced world, the current and future working environment has and will undergo many significant changes. Thus, employees' competencies are needed to support the vision and mission of the organisation. Meanwhile, crisis management tasks especially in the government sectors in developing countries have established legal, administrative, logistic, and technical methods to handle or prevent crises efficiently (Mohd Rasdi et al., 2021; Simak, 2004).

In the context of Malaysian local authorities, this study is important as it assists the government in coordinating human resource development towards enhancing the country's competitiveness and prosperity. It also contributes to improving their services in line with the dynamic changes in the current working environment. The research scope in this field particularly in Malaysia is very broad. Thus, the researcher will discuss from a specific approach on how the crisis occurs and is being addressed by the organisation. The researcher will also emphasise on the disaster factor as one of the critical crises in this country. Accordingly, this study focuses on the practical study of applying competencies during the crisis. A case study of Pasir Gudang City Council (MBPG), one of the local authorities in Malaysia, is chosen in this study. This study aims to explore the understanding of crisis management competencies among people involved in the organisation.

It is stated in prior studies that every community, municipality, district, and organisation has the potential to manage the crisis that occurred in any situation. Besides, the survival of an entity or group depends on the quality and level of preparedness of the crisis management team, the efficiency of the contingency plan implementation, and the situation monitoring after the crisis. Timely, decisive, and effective actions or interventions can significantly contribute to crisis reduction (Tej et al., 2014). Therefore, good competency development strategies in dealing with disaster crises among employees are very important (Norazura, 2015). Crisis management involves the preparation of pre-crisis, during-crisis, and post-crisis, in line with prior findings (Minton \& Pease-Carter, 2011; Morris \& Minton, 2012; Zaremohzzabieh \& Samah, 2013).

However, some of the crises cannot be resolved in advance if there is no specific standard of procedures in dealing with them at the local authority level. Other than that, the competence of civil servants in question led to much research conducted (Zhong, 1998; Shah et al., 2004; Hunt \& Baruch, 2003; Che Su, 2012) to identify the root causes as well as to suggest various solutions or strategies in providing excellent services to the customers or stakeholders (Norfariza \& Nur Fadhillah, 2018).

Based on previous studies, the researcher found that there are no specific procedures or guidelines related to the current challenges, global and digital world, creative thinking, in-house training, and suitable skills among employees in dealing with any crisis. Therefore, this study may benefit MBPG in realising employees' personality development and enhancing their understanding of the work or situation. At the same time, this study will give a positive impact to the community, society, and stakeholders on the potential and 
competency level of MBPG employees.

A qualitative study enables researchers to form strategies to ensure descriptive, thorough, and impactful discovery in the aspect of human resource development when dealing with crises. According to the usual or current practices in any organisation, this study will explore more on human resource development that involves all levels of employees. Other than that, organisational learning that requires the talents and abilities of employees can be identified. This is also influenced by the community practices which ultimately lead to the improvement of human resources quality in the organisation.

\section{Literature Review}

\subsection{Contingency Theory}

One of the relevant theories related to this study is the contingency theory. This theory emphasises the importance of a leader's personality and the situation in which the leader operates his or her works. This is essential because the organisation needs proactive, responsive, and reactive leaders to lead the work process. Besides, the theory aims to connect leaders with appropriate conditions. Hence, it can be assumed that the organisation's ability to handle issues is depending on its leaders as well as their styles and situations (Northouse, 2018; Rami et al., 2018; Yukl, 2013).

The contingency theory also states the need for leaders to adapt their behaviours and styles based on the rational understanding of the current situation. Therefore, it is believed that there are better and worse leadership styles, and there is no "one measure for all" approach in leadership. This is because it depends on various situations faced by the leaders. According to Tosi Jr (1984), contingency theory has been an important part of the management literature for the last twenty years. The theory has developed over time in response to the classical theory which advocated only "one best way" to manage the organisation.

On the other hand, contingency theory explains that the organisational structure and management style relies on a group of "contingency factors", which are the surrounding uncertainty and instability. Based on the contingency theory, leadership style is described as "task-motivated" and "relationship-motivated" (DuBrin, 2012). This is in line with Fiedler's (1967) model that assumes personal leadership styles are task-oriented or relationship-oriented.

Task-oriented leaders tend to be autocratic and focus on getting work done. Meanwhile, relationship-oriented leaders put people first and apply creativity and teamwork to finish the projects. The leadership style can be determined through a technique developed by Fiedler, known as "Least Preferred Co-worker" (LPC). The LPC test requires the leader to think about the person who dislikes working the most among employees. Then, the person needs to be evaluated based on several factors namely cooperation, kindness, honesty, trust, and perspective. Fiedler (1967) mentioned that leaders who give high marks to LPCs are relationship-oriented. Fiedler's model can help in adapting the leadership style to a particular situation. This model is believed to gain the most effective results, where good relationships and responsible or structured leadership style are required to enhance the employees' 
competencies as well as to achieve the organisational development needs.

\subsection{Scenarios and Issues of Competency Development}

Various issues can be identified in an effort to develop organisational competencies. According to Fauziah (2019), the organisation faces daily obstacles and competitions in line with human resource development. In developed countries, many organisations demonstrate their success through effective human resource practices along with the improvement of skills and expertise among their employees.

Based on the crucial needs at the global level, organisations in Malaysia need to enhance their human resource growth to strengthen their roles and responsibilities. Therefore, human resources can be seen as the main drive in formulating and implementing policies related to human resource development at the national level. This includes the coordination and implementation of labour standards and policies, ensuring a conducive and harmonious working environment, promoting a safe, healthy, and dynamic work culture, strengthening the social safety net, and producing highly skilled, relevant, and competitive human capital.

\subsection{Crisis Management Competencies}

According to Mikusova and Horváthová (2019), crisis has been applied in many other terms such as disaster, business disruption, and emergency. Crisis may occur temporarily or permanently without any warning signs (Mehr \& Jahanian, 2016). It also depends on the level of threat, time pressure, and severity of the occurrence.

The researcher realises that no matter how efficient emergency management is, it is impossible for the organisation to avoid all crises. Over time, the crisis may be reduced in some areas, but there are possibilities for other kinds of crisis to emerge. Based on a crisis management approach, when unwanted events are rarely happening, the crisis threshold is lowered dramatically. However, this is riskier as the upcoming major events will be more devastating. The established policies are used as guidelines for prevention, mitigation, and conservation purposes. In addition, crisis management needs to take action and communicate with organisational leaders in reducing the likelihood of crisis.

In the private sector, the term 'crisis management' refers to all emergencies and potential hazards to the company. Meanwhile, in the public sector, the term generally refers to unforeseen or unplanned events due to any reason. It may cause damages, death, or financial loss to the organisation or community (Auf Der Heide, 1989; Drabek \& McEntire, 2003; Aziz et al. 2021).

\subsection{Characteristics of Crisis Management Competencies}

Some important characteristics as mentioned in the literature are self-confidence, resilience, firmness, energy, need for achievement, willingness to take responsibility, flexibility, service motivation, personal integrity, and emotional maturity. Furthermore, essential skills comprise communication skills, social skills, influencing and negotiating skills, analytical skills, technical skills, and life-long learning. The elements of behavioural leadership are related to the functional actions namely getting things done, working with people, and providing 
organisational focus. Meanwhile, task-oriented behaviours consist of job monitoring and evaluation, operational planning, and explanation.

\section{Methodology}

The researcher has chosen a qualitative method to discover the significance of the phenomenon in terms of thinking styles, perspectives, and beliefs. Other than that, this method will explain more about the phenomenon and strengthen the study findings. The researcher also applied a qualitative method for data collection, data analysis (inductive and deductive), and theme setting (Cresswell, 2018). This qualitative research also aims to answer the research questions through detailed exploration, observation, and extraction that will be explained descriptively and deductively throughout the study. Mursyid (2016) stated that this method is suitable for determining experiences, getting a better understanding of the process, and stating recommendations for the next steps.

The research is based on a systematic process that involves the planning of research methodology, data collection, data analysis, and information reporting (Chua, 2011). The researcher acts as the primary instrument by collecting data through document examination, observation, and conducting interview sessions. The data collection method used in this study is a structured and in-depth interview with informants. Semi-structured questions were established for this purpose. In addition, the study informants were selected through a purposive sampling method. By using this method, the employees of MBPG were chosen by the researcher as the informants of this study. The following subsections will elaborate on the research steps and participants' characteristics.

\subsection{Selection of Informants}

Firstly, the researcher has decided to select MBPG as the case study to explore the crisis management competencies among the employees. Hence, the qualified informants are the ones who are dominant and can represent the whole population. Before selecting the informants, the researcher examined several aspects in the field such as relevant documents and information related to the case study. The sample size in this study is also determined by several factors related to the research purposes. For this reason, eight informants were chosen among MBPG employees to provide the required information.

\subsection{Characteristics of Informants}

The employees who met the selection criteria were selected as the informants or study participants. The criteria are MBPG employees consisting of Leaders (Mayor/President/Secretary) who have served MBPG within five years, and their Followers or people led by leaders (Officer A, Officer B, Implementation Groups C and D) who have served more than ten years. These informants are among the pioneers leading the crisis management in Pasir Gudang. Hence, they are the most appropriate persons to represent the organisation in this study. In order to maintain confidentiality, they were labelled as Informant 1 to Informant 8. 


\subsection{Sampling Procedures}

The researcher used informant selection criteria using purposive sampling in this study. Three things need to be taken into account in the qualitative study, namely the participants as the study sample, type of sampling strategy, and sample size.

\subsection{Steps and Covariates}

A detailed procedure during the data collection phase was prepared by the researcher. The elements of the pilot study and actual study, structured interview method, probing technique, and ethics in the study are discussed. The pilot study was conducted with the informants who meet the criteria set in this study. The selection of this interview method is aimed at obtaining in-depth and accurate data from the informants. Besides, the probing technique during the interview was applied to assist the researcher in asking flexible and appropriate questions to the informants.

\subsection{Research Design}

The interview protocol was used as a data collection tool, in which the relevant questions asked during the interview session would answer the research questions. The questions comprise open-ended ones that will give some space to the informants in expressing their views. The researcher needs to lead the interview session in order to prevent informants from being strayed to matters or explanations that are not related to the study.

\subsubsection{Pilot Study and Actual Study}

A pilot study is a small-scale preliminary study. It is one of the important phases in conducting research, where the researcher will test the study process to identify potential issues, weaknesses in the research instruments, and research protocols before the actual study. The pilot study will help the researcher to be more aware of the procedures and protocols as well as to select the appropriate method in this study. For example, the semi-structured interview technique is chosen in this study after being compared to the open interview technique.

According to Merriam (2009), there are three success keys to conducting an interview. The researcher needs to enhance self-skills by having a good personality, required skills, behaviours, orientation, and comprehensive understanding of certain situations.

Throughout this pilot study implementation, the researcher will observe and identify problems that may arise before conducting it in the field. This gives an opportunity to the researcher in overcoming the problems and enhancing his or her capability in any condition. Besides, the researcher can prepare for any possible situations and give attention to the implementation process in the actual study. The researcher also may estimate the cost requirements and length of period required during the operations of the study.

In conclusion, the researcher can identify whether the research goals and design are realistic to be implemented in the actual study based on the challenges encountered during the pilot study. This is because the researcher will test the informants via a two-way discussion based 
on the interview protocol. At the same time, the researcher may discover the next steps or ways to proceed with the study, the best method as well as the required time and resources of the study.

\subsubsection{Interview Arrangement}

The method used in achieving the study findings is according to the research questions. The interview will begin with an introductory session and a relaxed and enjoyable conversation session so that the informant feels comfortable. There are three main phases of the interview session. Firstly, the researcher will introduce the research topic with informants in general. The second stage is the main phase of the process, where all questions are being asked by the researcher using keywords or key questions in order to dig out problems and to gain answers or views from the informants. The construction of the questionnaire leads to several important pieces of information that will be applied as the basic data for this research. Finally, the third stage is the summary phase for the interview sessions with the informants. At this stage, if some issues are still unclear, the researcher will try to ask or discuss them again with the informants.

The probing technique is conducted in a structured way, where the researcher will thoroughly discuss each question until they are fully developed and summarised by the researcher. Informants will be allowed to express their comments, hopes, and perspectives on the research.

\subsection{Experimental Intervention or Manipulation}

To ensure the reliability of the study, the researcher needs to fully understand the ethical code on ethical issues throughout the process of exploration and investigation in this qualitative study.

\section{Data Analysis}

To achieve the study's potential in giving description, explanation, and prescription, it is important to identify the relevant concepts for the purpose of creating and validating the constructions of the theory. Finally, both theory building and testing are crucial to fulfill the study with big potential in terms of its utility, presence, and originality (Corley \& Gioia, 2011).

The researcher attempts to describe a holistic approach to the development of inductive concepts in order to balance the research requirements. Gioia et al. (2013) in their study highlighted the interpretation of the informants and the researcher's main role in giving a clear picture of the informants' experience.

This method gives an opportunity for the informants to voice out their opinions during the early stages of data collection. After that, the researcher plays a role in representing their voices or ideas in the data analysis stage as well as in the research reporting. Therefore, there are chances of the discovery of new concepts, assertion of the existing concepts, and also the formulation of relevant theories (Gioia et al., 2013). 


\section{Macrothink}

International Journal of Human Resource Studies

ISSN 2162-3058

2021, Vol. 11, No. 4S

Data analysis is a very important process to analyse and interpret the findings of the study as well as to answer the research questions. Therefore, the collected data and information need to be analysed descriptively so that it will be easier to understand and develop the final conclusions of the study. Figure 1 shows the important steps of data analysis in this study.

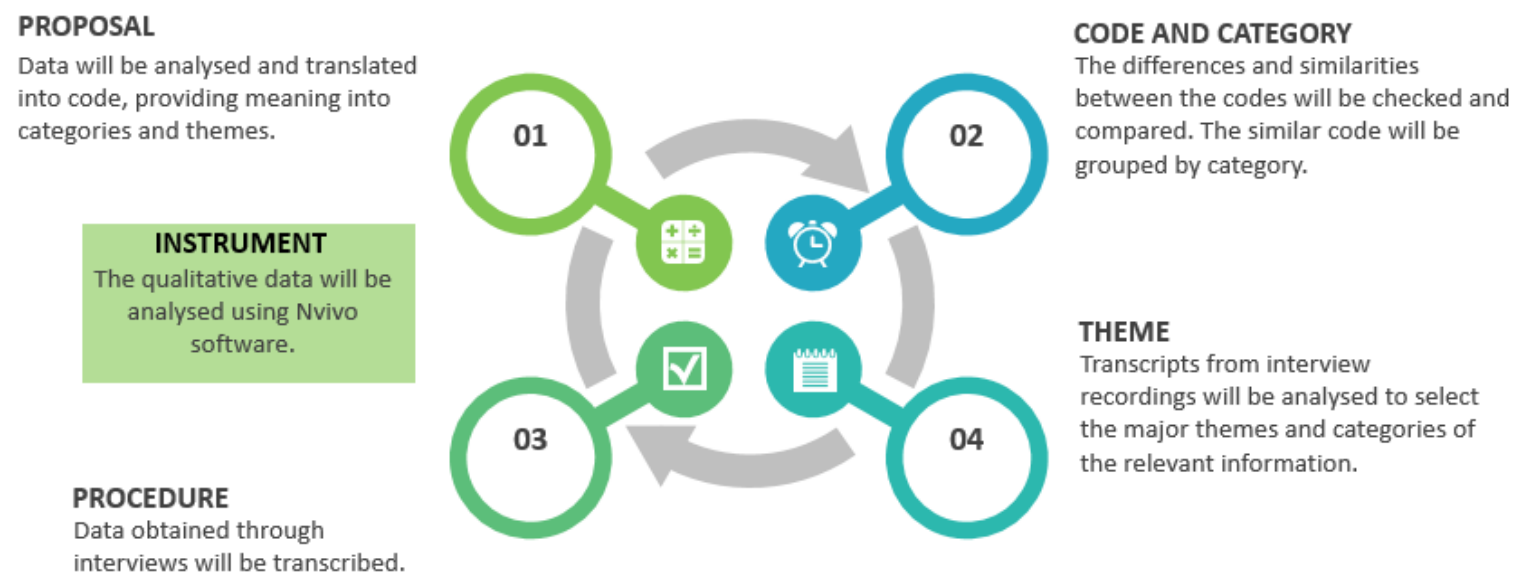

Figure 1. Data Analysis

A transcription process is a process of converting recorded research findings (audio or video) into text format. It is done by relistening to the interview recording and retyping the words into the document. After that, the researcher used NVivo software for data management and data storage purposes. The obtained data were organised and coded properly to facilitate the research process.

After the data was successfully analysed, the researcher provided a detailed description regarding the findings of the study, as a result of the interview session with the informants. For this purpose, the researcher set the code, developed the theme, and classified and interpreted the data accurately. In the process of classifying the code into themes, the development of ideas through validity in the data analysis process is mainly derived from readings and reviews. Meanwhile, significant statements about the experiences of informants are classified as textural and structural descriptions (Mursyid, 2016).

\subsection{Credibility, Transferability, Reliability, and Validity}

In qualitative research, the concepts of validity and reliability can be categorised into two aspects, namely internal validity and external validity. According to Carpenter and Suto (2008) and Cresswell (2018), internal validity is defined as credibility, while external validity is referred to as transferability. For this purpose, all important information are recorded in the field notes. Data storage is also stored and classified into respective folders of informants. 
Table 1. Study Informant Profile

\begin{tabular}{|c|c|c|c|c|c|}
\hline Informant & $\begin{array}{c}\text { Age } \\
\text { (year) }\end{array}$ & $\begin{array}{l}\text { Period of } \\
\text { service }\end{array}$ & $\begin{array}{l}\text { Period of } \\
\text { service in } \\
\text { MBPG }\end{array}$ & Position & Notes \\
\hline Informant 1 & 54 & 25 years & $\begin{array}{l}1 \text { year } \\
3 \text { months }\end{array}$ & President & $\begin{array}{c}\text { (Johor State } \\
\text { Administrative Officer) }\end{array}$ \\
\hline Informant 2 & 60 & 35 years & $\begin{array}{l}1 \text { year } \\
6 \text { months }\end{array}$ & President & $\begin{array}{c}\text { (Johor State } \\
\text { Administrative Officer) }\end{array}$ \\
\hline Informant 3 & 44 & 21 years & 6 years & Secretary & $\begin{array}{c}\text { (Johor State } \\
\text { Administrative Officer) }\end{array}$ \\
\hline Informant 4 & 46 & 23 years & 2 years & President & $\begin{array}{c}\text { (Johor State } \\
\text { Administrative Officer) }\end{array}$ \\
\hline Informant 5 & 60 & 30 years & 20 years & $\begin{array}{l}\text { Deputy } \\
\text { Secretary }\end{array}$ & MBPG Permanent Staff \\
\hline Informant 6 & 55 & 35 years & 33 years & $\begin{array}{l}\text { Administrative } \\
\text { Assistant }\end{array}$ & MBPG Permanent Staff \\
\hline Informant 7 & 58 & 37 years & 37 years & $\begin{array}{l}\text { Administrative } \\
\text { Assistant } \\
\text { (N26) }\end{array}$ & MBPG Permanent Staff \\
\hline Informant 8 & 35 & 11 years & 11 years & $\begin{array}{l}\text { Assistant } \\
\text { Valuation } \\
\text { Officer }\end{array}$ & MBPG Permanent Staff \\
\hline
\end{tabular}

\subsection{Research Findings}

The results of this study are hoped to answer the established research question:

What is understood about crisis management competencies among employees in the organisation?

The findings also discovered four main themes regarding crisis management competencies, which are in accordance with participatory observations, document analysis, and interview sessions that have been conducted. The themes are as follows:

1. Excellent work culture

2. Dynamic thinking competency learning

3. Efficient organisational production

4. Responsive governance development

These four themes can provide understanding to the researcher regarding the perspectives of MBPG employees at the management and implementation levels in handling any crisis.

\subsubsection{Excellent Work Culture}

From the interviews, majority of the informants agreed that excellent work culture is the backbone towards organisational success. The relationship of excellent work culture and competency development can be observed in the process of handling the crisis. In addition, excellent work culture is based on the competence level of each employee that has been cultivated in the organisation. Several elements instilled in every individual and organisation are positive culture, high commitment to the organisation, excellent work performance, 
concentration at work, good attitude, high skills, accountability, experience, obeying the leader's instructions, teamwork, talent development opportunities, corporate thinking cultivation, training, human capital development, and appreciation from the organisation.

A corporate work culture develops the organisation and rapidly transforms the organisation. This shows that the employees' personality development has been established by previous leaders towards organisational success. As mentioned by the Informant 3:

“...I am grateful because I am given the opportunity to work at a good local authority. I have to adjust immediately and work quickly. Most of the employees are those who have served for many years, such as heads of departments and officers. They apply corporate culture in their daily work..."

\subsubsection{Dynamic Thinking Competency Learning}

Good leadership, effective management methods, efficient delivery system to external parties, and efficient task implementation are among the criteria observed by the management in building crisis management competencies. The criteria are integrated so that leaders can collaborate with employees to improve organisational productivity. Besides, all staff strives to create a learning organisation by sharing their knowledge with each other while performing the tasks. Employees who go through the learning process may enhance their thinking competencies.

Furthermore, the management needs to have good leadership, proactive and reactive in improving production quality, upgrade the delivery system, and increase the effectiveness of change management. Informant 1 stated that learning organisation can be enhanced through strong or good relationships between the leaders and employees.

"... Most of the leaders here, such as heads of the departments can successfully lead their subordinates. They also have good leadership characteristics. For instance, when KIK competition is being held, they are willing to be together at every stage, no matter at the department, zone, national levels, and even at the international level. That is why I am very proud of this organisation..."

In addition, Informant 5 acknowledged the improvement of effective management methods in MBPG:

"In my opinion, we have efficient workers in every aspect from top management to the lower ones. All of them will be involved in any event or program in MBPG. We will make sure that each employee, whether he/she is weak or strong, to unite according to the tasks. The leaders will also ensure that the tasks are implemented successfully along with their strong commitments..."

Based on the examples, the organisational learning process is seen to produce high competencies among employees when dealing with crises. Although some employees are still ignorant during the learning process, but good leadership produces dynamic thinking. 


\subsubsection{Efficient Organisational Production}

From the interviews and observations, it was discovered that the organisation should always prepare for efficient organisational production, approaches to overcome internal and external challenges, and identify the current issue and crisis from time to time. This is crucial to prevent any severity or serious situation in the future. Besides, periodic planning by the management can help to solve internal challenges in organisational development. However, external challenges are crucial to be successfully solved by the employees. Informant 1 explained that:

"...An employee must be skilled in terms of practicality in the field, not only in management, but he/she must have the skills to directly solve any issue or challenges outside the organisation..."

Meanwhile, Informant 4 elaborated on great challenges faced by the organisation while managing its administration:

"...Some big challenges faced by MBPG in managing the industrial sector, namely environmental control and environmental management. There are a lot of industrial issues in Pasir Gudang, not only related to the light industry. There are three levels; heavy, medium, and light industries..."

Besides looking at the type of challenges, the current issues or crises also help organisations in raising awareness related to crisis management competencies. Awareness of roles and responsibilities have to be taken into consideration by the management and employees to ensure a more efficient organisation.

\subsubsection{Responsive Governance Development}

In understanding the development of competencies to deal with crises, organisational learning efforts through research on existing strengths, weaknesses, and potentials are required to realise responsive governance in the organisation.

Based on interviews with informants, some various advantages and potentials exist in the organisation, such as good leadership team, formation of corporate culture, good task force, value of togetherness, increase in the number of employees, adequate financial resources, and high responsibility in achieving the organisational mission and vision. On the other hand, some disadvantages need to be improved, namely non-compliance with procedures, value deterioration, and lack of enthusiasm among the employees over time. Informant 5 explained the value of togetherness and responsibility in achieving the organisational mission and vision:

“...All achievements and targets have been set by top management. In fact, we have a program every year, namely a strategic management workshop. During the program, we will discuss our goals and objectives, how to achieve them, what the end result is, and we will review the matters together..."

This is in line with the opinion of Informant 4, who also acknowledged that all employees 
have worked together to improve the organisation in accordance with its mission and vision:

“...One of the MBPG's taglines is 'A port and industrial city'. Actually, this tagline greatly influences our competency development. Apart from that, it is related to our ways in managing problems and supervising related industries in terms of environment and other relevant matters..."

\section{Discussions and Conclusions}

This study found that there is a variety of understanding in assessing the crisis management competencies. Some perspectives in assessing crisis management competencies in MBPG are excellent work culture, dynamic thinking, competency learning, efficient organisational production, and responsive governance development. In this case, the excellence of MBPG is based on a high level of understanding of crisis management competencies among all employees, including top management and other employees. The excellent work culture in MBPG also comprises positive elements in its corporate thinking culture, which makes this organisation more competitive and on a par with the development of other local authorities.

In addition, MBPG always implements competency learning to produce dynamic thinking among leaders. This is observed through the existence of a good leadership series among leaders, effective management methods, efficient task implementation, and readiness in dealing with crisis according to MBPG's capabilities. With such a clear understanding, organisational learning can be implemented easily.

Based on prior studies, strategies in crisis management competencies are strongly needed by all employees in the organisation. In the Malaysian context, the elements to strengthen the competencies of top management and staff as well as the need for crisis management competencies are less discussed in the administrative landscape. At MBPG, efficient organisational development looks at internal challenges, external challenges, types of challenges, as well as current issues and crises to provide opportunities for management and employees to jointly develop the organisation. This is because crisis management competencies require readiness in making changes, such as the discussion process to solve problems, reorganise, resolve crises, and many more.

Overall, management and employees have understood the value of crisis management competencies when they work together as a team in achieving the MBPG's mission and vision. They also feel the value of togetherness based on the formation of a corporate culture that has long been adapted to produce responsive governance. However, the challenges that occur can influence the ways of thinking and reduce the employees' values and morale while facing the crisis. The same thing goes for those who do not follow procedures and affect teamwork. Therefore, leaders play an important role in providing awareness and guidance to employees on the organisational learning process. Crisis management competencies also give a positive impact when there is preparedness by those responsible for planning and reorganising tasks after the crisis.

\subsection{Implications}


The understanding of crisis management competencies among leaders and their followers needs to be refined. This is because they are the domain of the organisation and also the implementers of policies set by the government. In addition, every local authority is responsible for managing their respective administrative areas. In the face of a crisis, the intervention of other forces is expected to take place. As a result, it will interfere with the implementation of the solutions by the organisation.

In line with today's various challenges, the responsibility of resolving every crisis faced by local authorities must be well coordinated. In addition, the duties of leaders need to be enhanced in order to bring employees together in creating success when dealing with crises.

\subsection{Limitations and Recommendations for Future Research}

Among the study limitations discovered by the researcher is that this study only focuses on one local authority, namely MBPG. Therefore, the results of this study may not reflect the practices in other local authorities. However, the implementation of this qualitative study has the potential to be extended further in finding the meaning and understanding the governance of the organisation, especially related to the crisis management competencies among management and employees. At the same time, the framework of this study can be used as a reference for other local authorities in conducting research related to this field.

\section{Acknowledgement}

I would like to express my gratitude to Universiti Putra Malaysia, especially my supervisors, Prof. Dr. Ismi Arif Ismail, Assoc. Prof. Dr. Mohd Mursyid Arsyad, and Dr. Ahmad Aizuddin Md Rami for your guidance. Thank you to my partner, Mr. Md Abd Aziz Md Taufik for our daily valuable discussions.

\section{References}

Auf der Heide, E. (1989). Disaster response: Principles of preparation and coordination. St Louis, MO: C. V. Mosby Company.

Aziz, F., Md Rami, A. A., Zaremohzzabieh, Z., \& Ahrari, S. (2021). Effects of Emotions and Ethics on Pro-Environmental Behavior of University Employees: A Model Based on the Theory of Planned Behavior. Sustainability, 13(13), 7062. https://doi.org/10.3390/su13137062

Beram, S., Awang, M., \& Ismail, R. (2020). Pembangunan model kompetensi pemimpin pertengahan: Satu kajian reka bentuk dan pembangunan. Journal of Educational Research and Indigeneous Studies, 2(1), 1-10

Carpenter, C., \& Suto, M. (2008). Qualitative research for occupational and physical therapistsa practical guide. Blackwell Pub.

Che Su, M. (2012). Kompetensi komunikasi dan kepuasan komunikasi penjawat awam di Malaysia. Jurnal Pengurusan (UKM Journal of Management), 43, 13-26. https://doi.org/10.17576/pengurusan-2015-43-02

Chua, Y. P. (2011). Kaedah dan statistik penyelidikan: Kaedah penyelidikan. Shah Alam: Mcgraw-Hill Education. 


\section{Macrothink}

International Journal of Human Resource Studies

ISSN 2162-3058

2021, Vol. 11, No. 4S

Corley, K. G., \& Gioia, D. A. (2011). Building theory about theory building: What constitutes a theoretical contribution?. Academy of Management Review, 36(1), 12-32. https://doi.org/10.5465/amr.2009.0486

Creswell, J. W. (2018). Research design: Qualitative, quantitative, and mixed methods approaches. London: Sage Publications.

Drabek, T. E., \& McEntire, D. A. (2003). Emergent phenomena and the sociology of disaster: Lessons, trends and opportunities from the research literature. Disaster Prevention and Management, 12(2), 97-112. https://doi.org/10.1108/09653560310474214

DuBrin, A. J. (2012). Narcissism in the workplace: Research, opinion and practice. Edward Elgar Publishing. https://doi.org/10.4337/9781781001363

Fauziah, L. (2019). Pengembangan sumber daya manusia berbasis kompetensi dalam meningkatkan perekonomian di Kabupaten Pemalang. In Prosiding Seminar Nasional Fakultas Ekonomi Untidar.

Fiedler, F. E. (1967). A theory of leadership effectiveness. McGraw-Hill Series in Management.

Gioia, D. A., Corley, K. G., \& Hamilton, A. L. (2013). Seeking qualitative rigor in inductive research: Notes on the Gioia methodology. Organizational Research Methods, 16(1), 15-31. https://doi.org/10.1177/1094428112452151

Ghozali, I., Iswati, S., \& Adam, S. (2020). Pengembangan sumber daya manusia berbasis kompetensi sebagai upaya meningkatkan kinerja organisasi di PT. Ekonika: Jurnal Ekonomi Universitas Kadiri, 5(2), 211-223. https://doi.org/10.30737/ekonika.v5i2.1094

Hecklau, F., Galeitzke, M., Flachs, S., \& Kohl, H. (2016). Holistic approach for human resource management in Industry 4.0. Procedia Cirp, 54, 1-6. https://doi.org/10.1016/j.procir.2016.05.102

Hunt, J. W., \& Baruch, Y. (2003). Developing top managers: The impact of interpersonal skills training. Journal of Management Development, 22(8), 729-752. https://doi.org/10.1108/02621710310487882

Lenggan, L. (2019). Pengaruh kompetensi diri terhadap kinerja pekerja GKII Daerah Kota Samarinda. Jurnal Jaffray, 17(2), 223-238. https://doi.org/10.25278/jj.v17i2.366

Md Rami, A. A., Aziz, M. F. A., Nasharudin, N. A. M., \& Rasdi, R. M. (2021). Characteristics and Success Factors of Rural Community Leadership in Malaysia: A Focus Group Analysis. Pertanika Journal of Social Sciences \& Humanities, 29(3). https://doi.org/10.47836/pjssh.29.3.07

Mehr, M. K., \& Jahanian, R. (2016). Crisis management and its process in organization. Mediterranean Journal of Social Sciences, $7(5 \quad$ S1), 143-143. https://doi.org/10.5901/mjss.2016.v7n51p143

Merriam, S. B. (2009). Qualitative research: A guide to design and implementation. San Francisco, CA: John Wiley \& Sons.

Mikušová, M., \& Horváthová, P. (2019). Prepared for a crisis? Basic elements of crisis 
management in an organisation. Economic research-Ekonomska istraživanja, 32(1), 1844-1868. https://doi.org/10.1080/1331677X.2019.1640625

Minton, C. A. B., \& Pease-Carter, C. (2011). The status of crisis preparation in counselor education: A national study and content analysis. Journal of Professional Counseling: Practice, Theory \& Research, 38(2), 5-17. https://doi.org/10.1080/15566382.2011.12033868

Morris, C. A. W., \& Minton, C. A. B. (2012). Crisis in the curriculum? New counselors' crisis preparation, experiences, and self-efficacy. Counselor Education and Supervision, 51(4), 256-269. https://doi.org/10.1002/j.1556-6978.2012.00019.x

Mursyid, A. M. (2016). Pembangunan belia positif melalui proses pementoran dalam program kepemimpinan belia di Malaysia (Doctoral Dissertation, Universiti Putra Malaysia).

Norazura, A. (2015). Kaunseling krisis: Kecekapan kaunselor dalam mengendalikan krisis bencana di Malaysia. Seminar Serantau Viii, Universiti Kebangsaan Malaysia, Selangor.

Norfariza, R., \& Nur Fadhillah, M. (2018). Tahap kompetensi guru dalam pelaksanaan kemahiran berfikir aras tinggi di sekolah kebangsaan Daerah Sepang, Selangor. JuKu: Jurnal Kurikulum \& Pengajaran Asia Pasifik, 6(4), 12-28.

Norhani, B., \& Yoong, S. K. (2009). Hubungan antara peranan individu dan organisasi dengan amalan pembangunan kerjaya. Journal of Human Capital Development, 2(1), 13-24.

Northouse, P. G. (2018). Leadership: Theory and practice (8th ed.). Thousand Oaks: Sage Publications.

Rami, A. M., Abdullah, R., \& Ariffin, W. J. (2018). Strengthening social capital: Local leader's strategy toward developing rural community. International Journal of Academic Research in Business and Social Sciences, 8(1), 765-774. https://doi.org/10.6007/IJARBSS/v8-i1/3846

Rusle, R. (2018). Kompetensi revolusi perindustrian 4.0 dalam kalangan staf kolej komuniti. BITARA International Journal of Civilizational Studies and Human Sciences, 1(2), 89-97.

Shah, M. B., King, S., \& Patel, A. S. (2004). Intercultural disposition and communication competence of future pharmacists. American Journal of Pharmaceutical Education, 68(5), 2-11. https://doi.org/10.5688/aj6805111

Simak, L. (2004). Krízový manažment vo verejnej správe. Žilina: FŠI ŽU, 243.

Tej, J., Zivcak, P., Taha, V. A., \& Sirkova, M. (2014). Crisis awareness of the municipal district residents: implication for crisis management at the local government level. Quality Innovation Prosperity, 18(2), 1-14. https://doi.org/10.12776/qip.v18i2.295

Tosi Jr, H. L., \& Slocum Jr, J. W. (1984). Contingency theory: Some suggested directions. Journal of Management, 10(1), 9-26. https://doi.org/10.1177/014920638401000103

Triyanto, A., \& Sudarwati. (2014). Pengaruh kompetensi dan penghargaan terhadap motivasi kerja karyawan PT. KAI di Stasiun Sragen. Jurnal Paradigma, 12(1), 26-40.

Yostan, L. A. (2019). Konsep pengembangan sumber daya manusia berbasis kompetensi, bakat dan ketahanan dalam organisasi. Jurnal Manajemen \& Kewirausahaan, 7(1), 28-35. 
https://doi.org/10.26905/jmdk.v7i1.2760

Yukl, G. A. (2013). Leadership in organisations ( $8^{\text {th }}$ ed.). Boston: Pearson Education.

Zaenudin, T. (2018). Faktor pendukung karyawan untuk meningkatkan produktivitas organisasi bisnis. Ikra-Ith Ekonomika, 1(2), 19-24.

Zaleha, Y., Abdullah, N. A., \& Baharom, R. (2017). Konflik dalam proses penilaian prestasi dalam organisasi. Jurnal Pengurusan (UKM Journal of Management), 49(2017), 41-52. https://doi.org/10.17576/pengurusan-2017-49-04

Zhong, M. (1998). Perceived intercultural communication competence in cross-cultural interactions between Chinese and Americans. Critical Studies, 12, 161-179.

\section{Copyright Disclaimer}

Copyright for this article is retained by the author(s), with first publication rights granted to the journal.

This is an open-access article distributed under the terms and conditions of the Creative Commons Attribution license (http://creativecommons.org/licenses/by/4.0/). 